\title{
STRATEGI STUDENT TEAMS' ACHIEVEMENT DIVISIONS (STAD,) DALAM MENINGKATKANKEMAMPUAN MENULISNARASISISWA SMK TELKOM MAKASSAR
}

\author{
B. Syukroni Baso
}

\begin{abstract}
Abstrak
Berdasarkan hasil pencermatan penulis bersama guru mata pelajaran bahasa Indonesia, ternyata kemampuan menulis siswa kelas X SMK Telkom Makassar masih tergolong rendah. Padahal, kemampuan dibidang ini sangat bermanfaat dalam menunjang kemampuan berbahasa siswa, dan terlebih lagi dalam menghadapi ujian nasional dengan tipe soal yang sudah mengarah pada aspek penggunaan bahasa. Oleh karena itu, kemampuan menulis sangat penting dan mendesak dikuasai siswa. Menurut hasil diagnosis penulis bersama guru mata pelajaran bahasa Indonesia khususnya kelasX Telkom Makassar, ternyata akar penyebab masalah ini dapat diidenfikasi sebagai berikut (1) siswa sangat jarang diberikan kesempatan mengembangkan kemampuan menulis karangan narasi, (2) siswa lebih sering disuruh menghafal jenis-jenis paragraf, tanpa diminta mencoba menulis paragraf, (3) pelajaran menulis masih ditakuti siswa, (4) pelajaran menulis membosankan bagi siswa. Oleh karenaitu,Tujuan penelitian ini adalah, menarasikan implementasi pembelajaran kooperatif secara efektif, teristimewa bagaimana upaya peningkatan kemampuan menulis narasi siswa kelas X SMK Telkom Makassar melalui strategi student learns achievernent divisions (STAD) yaitu strategi pembagian prestasi keompok siswa. Kelompok tim yang berprestasi diberi hadiah atau penghargaan itu dilaksanakan pada tahap perencanaan pembelajaran, tahap pelaksanaan, dan tahap evaluasi pembelajaran. Pembelajaran kooperatif (cooperative learning) secara sadar menciptakan interaksi yang silih asah (saling mencerdaskan) sehingga sumber belajar bagi siswa bukan hanya guru dan buku ajar tetapi juga interaksi sosial diantara sesama siswa. Hal itu membuat siswa tetap berada dalam interaksi silih asih (saling mencintai). Pembelajaran kooperatif secara sadar dan sengaja mengembangkan pula interaksi yang dapat menyebahkan permusuhan (Nurhadi. 2004:61). Tes awal siswa kelas X SMK Telkom Makassar, mengisyaratkan bahwa perlu ada bantuan (1) meningkatkan kemampuan menuangkan gagasan dalam pembelajaran menulis narasi pada tahap pramenulis, (2) pembelajaran menulis narasi pada tahap menulis, (3) pembelajaran menulis narasi pada tahap pascamenulis, sehingga perlu dilaksanakannya menulis narasi. Kegiatan itu sebagai upaya peningkatkan kemampuan menulis narasi dalam cooperative learning.

Dalam pembelajaran kooperatif, guru menciptakan suasana yang mendorong agar siswa merasa saling membutuhkan. Saling ketergantungan positif menuntut adanya interaksi positif yang memungkinkan sesama siswa saling memberikan motivasi untuk meraih hasil belajar yang optimal yakni (I) saling ketergantungan pencapaian tujuan, (2) saling ketergantungan dalam menyelesaikan tugas, (3) saling ketergantungan bahan atau sumber, (4) saling ketergantungan peran, dan (5) saling ketergantungan hadiah.Penelitian tersebut menggunakan pendekatan kualitatif dengan rancangan penelitian tindakan kelas (classroom action research) yang dilaksanakan pada tahap perencanaan pembelajaran, tahap pelaksanaan, tahap observasi dan refleksi secara berdaur ulang dan kolaboratif sehingga implikasi praktis yang diperoleh dapat diterapkan secara langsung dalam perbelajaran.

Data penetitian adalah kegiatan pengamatan, wawancara, catatan lapangan serta aktivitas guru dan siswa termasuk hasil evaluasi belajara siswa. Peneliti berperan sebagai instrumen. Instrumen penunjang berupa pedoman.
\end{abstract}

\section{Kata kunci:Menulis narasi, strategi STAB, Sekolah Menengah Kejuruan}

\section{PENDAHULUAN}

Pada dasarnya pembelajaran keterampilan berbahasa hendaknya diorientasikan untuk berbagai keperluan komunikasi siswa dan berbagai bentuk strategi. Pendidikan menjadi hal yang sangat fundamental bagi kehidupan seseorang, dengan pendidikan yang baik maka akan baik pula pola piker dan sikap seseorang. Pendidikan yang baik terbentuk dari pola dan system pendidikan yang baik pula. Pola dan system pendidikan yang baik terwujud dengan kurikulum yang baik.Kurikulum yang baru yaitu kurikulum 2013 sudah diterapkan di beberapa sekolah di Indonesia. Perspektif ini makin keras dihembuskan oleh Kurikulum yang baru yaitu kurikulum 2013 Untuk mata pelajaran Bahasa dan Sastra Indonesia, dikembangkan suatu pendekatan yang berorientasi pada suatu pemahaman bahwa belajar bahasa adalah belajar berkomunikasi baik secara lisan maupun tulisan. Selanjutnya, dinyatakan bahwa pembelajaran bahasa Indonesia di persekolahan dalam kurikulum baru ini diarahkan untuk membangun, membina, dan meningkatkan kompetensi berbahasa siswa.

Namun, harapan tersebut tampaknya masih kurang mendapat perhatian yang serius meskipun guru-guru mengetahui bahwa seperti itulah pembelajaran bahasa Indonesia seharusnya dilakukan sebagai aktualisasi dari kurikulum 2013. Akan tetapi masih banyak guru belum berani melakukannya dengan alasan bahwa hal tersebut sulit dan tidak lazim dilakukan.Wajarlah jika, Syafei (2001) menyatakan bahwa interaksi yang 
terjadi dalam pembelajaran bahasa Indonesia hanya interaksi siswa dan buku teks, tidak terdapat interaksi antara siswa dengan siswa. Keadaan seperti inilah yang tampak mencolok dalam keseharian pembelajaran keterampilan berbahasa selama ini.Begitu juga halnya dalam menulis Badudu (1985) (Haryadi dan Zamzani, 1996:75) mengatakan bahwa rendahnya mutu kemampuan menulis siswa disebabkan oleh kenyataan bahwa pengajaran mengarang dianaktirikan. Hal tersebut tentunya akan berdampak pada hasil belajar siswa. Hasil belajar siswa merupakan salah satu indikator keberhasilan dari suatu proses pembelajaran yang nantinya akan berimbas pada keberhasilan pendidikan secara umum.

Model pembelajaran keterampilan berbahasa yang terdapat dalam buku pelajaran bahasa Indonesia perlu diperkaya dengan model-model lain yang memberi nuansa baru sehingga meningkatkan kompetensi komunikasi siswa. Selama ini model pembelajaran kurang menantang siswa, terutama gaya belajar yang monoton sehingga tidak memancing kreativitas siwa. Pengorganisasian materi pelajaran dalam kurikulum meliputi tiga komponen utama, yaitu (a) kompetensi dasar, (b) materi pokok, dan (c) indikator pencapaian hasil belajar. Selanjutnya, dinyatakan bahwa kompetensi dasar merupakan kemampuan yang harus dikuasai siswa dalam berkomunikasi lisan dan tulis sesuai dengan kaidah bahasa. Kompetensi tersebut dikembangkan secara terus-menerus untuk membangun tindak komunikasi dalam berpikir kritis dan kreatif, yang dapat dicapai melalui proses pemahiran yang dilatihkan dan dialami langsung oleh siswa.

Kenyataan di atas mengharuskan pembelajaran keterampilan berbahasa, dilakukan secara intensif. Namun, dewasa ini ada kesan yang berkembang di masyarakat bahwa mata pelajaran bahasa Indonesia merupakan mata pelajaran yang kering dan kurang bergengsi sehingga motivasi belajar siswa terhadap bahasa Indonesia tergolong rendah. Yusril, (2004) dalam penelitiannya menyimpulkan bahwa minat siswa SMK di kota Makassar terhadap mata pelajaran Bahasa Indonesia cukup rendah. Demikian pula halnya

\section{KAJIAN PUSTAKA}

H bisa dipahami oleh orang lain. Sedangkan menurut Akhadyah dkk (1988: 1) yaitu kemampuan mengungkapkan apa yang ada dalam pikiran dan perasaan seseorang tentang pemahaman, pengalaman, penghayatan, serta proses mengembangkan gagasan menjadi tulisan (lambang-lambang kebahasaan). Menurut Tarigan (1983: 21) hakikat menulis adalah menurunkan atau melukiskan lambang-lambang grafis yang dengan kesimpulan Fadlan (2006) yang menyatakan bahwa mata pelajaran bahasa Indonesia menduduki urutan keempat sebagai mata pelajaran yang diminati oleh siswa di Kota Makassar. Wajarlah jika kenyataan dewasa ini membuktikan bahwa hasil pembelajaran bahasa Indonesia, khususnya keterampilan berbahasa belum menggembirakan seperti yang diungkapkan oleh Dian (Kompas, 2001) bahwa banyak siswa gagal dalam menulis karena metode pembelajaran yang kurang efektif.

Pada dasarnya mata pelajaran bahasa Indonesia khususnya pembelajaran keterampilan berbahasa merupakan pelajaran yang variatif dan sangat menyenangkan dipelajari. Hal itu disebabkan oleh banyaknya wahana, sarana, alat, ataupun lingkungan di sekitar yang dapat dijadikan sebagai sumber belajar. Melalui pembelajaran keterampilan berbahasa yang kreatif dan inovatif, dapat meningkatkan motivasi belajar siswa sehingga secara tidak langsung dapat memberikan pengalaman baru kepada siswa untuk memahami, mengkaji, mengeksplorasi, dan menganalisis materi pelajarannya. Siswa memiliki banyak kesempatan untuk dapat mengungkapkan gagasan-gagasannya berdasarkan pengalaman yang diperoleh di lapangan, baik secara lisan maupun tulisan. Dengan demikian, secara tidak langsung terjadi pembelajaran lintas bidang studi antara bahasa Indonesia dengan bidang studi yang lain.

Hal itu menunjukkan bahwa tujuan berbahasa melalui pembelajaran bahasa Indonesia adalah untuk membina kemampuan menggunakan bahasa Indonesia dalam menyimak, berbicara, membaca, dan menulis. Keempat keterampilan ini biasanya dilaksanakan secara terpadu (Depdikbud, 1995: 21). Sehubungan dengan hal tersebut, keempat keterampilan berbahasa menurut Syafi'ie (2001: 17) bersumber dari kemampuan kebahasaan (language competence) dan kemampuan komunikatif (communicative competence).

\section{A. Hakikat Menulis}

menggambarkan suatu bahasa yang dipahami oleh seseorang sehingga orang lain dapat membaca pula lambang-lambang grafis itu, jika mereka memahami bahasa dan lambang grafis tersebut.

Bahasa tulis sangat diperlukan sebagai penyampaian isi pesan kepada orang lain dalam betuk tulisan. Oleh sebab itu, tulisan harus dapat dipahami oleh pembaca. Dengan demikian, penulis harus memiliki pula pengetahuan dan keterampilan dalam menggunakan bahasa tulis. Agar tulisan 
tersebut dapat dipahami pembaca, penulis juga harus menguasai bahasa pembaca sebagaimana yang diharapkan.

Hal itu menunjukkan bahwa menulis merupakan kegiatan yang sangat rumit dan kompleks. Oleb sebab itu, penulis hendaknya mengungkapkan gagasannya dengan jelas. Dengan kata lain, dia harus menggunakan bahasa dengan tepat, dan memahami siapa pembaca yang dituju.

Di samping itu, penulis harus memiliki keterampilan memilih dan menata gagasan sehingga pesan yang disampaikan mudah dipahami oleh para pembaca. Hal itu diperlukan karena kegiatan menulis merupakan bentuk kegiatan komunikasi secara tidak langsung. Sebaliknya, dalam komunikasi tidak langsung digunakan bahasa yang benar-benar efektif agar mudah dipahami oleh orang lain.

Sejalan dengan pendapat tersebut, Syafi'ie (2001: 45) mengemukakan bahwa untuk menghasilkan tulisan yang baik, penulis harus memiliki kemampuan khusus ke arah itu. Dia terlebih dulu harus (a) mengetahui masalah yang akan ditulis, (h) memahami kondisi pembaca, (c) menyusun perencannan penilaian, (d) menggunakan bahasa, (c) memulai tulisan, dan (f) memeriksa tulisan.

Tulisan akan menjadi efektif jika pertamatama penulis memiliki objek yang akan dikemukakan. Bila objek telah ditentukan, penulis harus memikirkan dan merenungkan gagasannya secara jelas. Kemudian dikembangkan gagasangagasan utamanya secara jelas dan rinci serta memilih dan menggunakan bahasa secara cermat untuk diungkapkannya.

Sehubungan dengan hal tersebut, Tarigan (1987: 3-4) menyatakan bahwa menulis merupakan suatu kegiatan yang produktif dan ekspresif. Selanjutnya, Nurgiyantoro (1987: 273) menyatakan bahwa dilihat dari segi kemampuan berbahasa, menulis adalah aktivitas mengemukakan gagasan melalui bahasa tulis. Aktivitas yang pertama memberikan penekanan pada unsur bahasa, sedangkan yang kedua pada unsur gagasan.

Selain itu, Suparno (2002: 13) mengatakan bahwa menulis dapat didefinisikan sebagai suatu kegiatan penyampaian pesan dengan menggunakan bahasa tulis sebagai alat atau medianya. Pesan adalah isi atau muatan yang terkandung dalam suatu tulisan. Tulisan merupakan sebuah simbol atau lambang, dengan demikian bahasa dapat dilihat dan disepakati pemakainya.
Hal menulis adalah sosial karena dapat dilakukan oleh siapa saja dalam konteks sosial dan interaksi sosial. Menurut Graves (1983) mengatakan bahwa menulis adalah satu proses sebab menurut penelitian, menulis yang dilakukan dalam 20 tahun terakhir sudah terpusat pada proses. Berpikir tentang proses menulis berarti berpikir tentang semua hal yang para penulis salah satu usia biasa dilakukan. Proses penulisansebagaimana yang dilukiskanoleh Graves (1983), yaitu "prewriting or planning, - thinking about writing; writing or transcribing - purling it down on paper; revising or reviewing - making changes.

Menurut Vygotsky (1978) (dalam Nurhadi, 2004) bahwa menulis adalah perkembangan yang dapat dilihat pada anak-anak dan yang berangsur-angsur menambah bentukbentuk abstrak, dan menggambar, membaca, dan menulis yang berkembang dalam keberwacanaan. Membaca dan menulis adalah proses interaktif, dinamik yang berorientasiarti. Hemowo, (2003) mengatakan bahwa gaya tulisan tidak didapati dari menulis, tetapi dari membaca. Menulis bisa membantu kita menyelesaikan masalah dan menjadikan kita semakin cerdas.

Selanjutnya, Graves (2003) menelusuri jejak perkembangan dan mengatakan seseorang dapat mengembangkan diri menjadi seorang penulis jika setiap kali ia berkecimpung dalam proses menulis. Sehubungan dengan itu, Hemowo (2003: 110) mengatakan hahwa gaya tulisan tidak didapat dari menulis, tetapi dan membaca. Menulis bisa membantu kita menyelesaikan masalah dan menjadikan kita scmakin cerdas. Graves (1994) menelusuri jejak perkembangan dan mengatakan bahwa menulis meningkatkan pembelajaran.

Setiap kali anak-anak menulis, periode penemuan terjadi dan mereka mendapatkan pengetahuan baru tentang menulis, membaca, dan berpikir selain pemaknaan yang lebih baik tentang diri sendiri. Anak-anak tidak tumbuh menjadi penulis melalui kemajuan linear, karena menulis bersifat berulang-ulang (rekursif). Syafi' ie (2001) telah menegaskan bahwa secara garis besar ada tiga tahapan dalam proses menulis, yaitu persiapan (prewriting), penulisan (composing), dan revisi (revision)

\section{B. Tujuan Pengajaran Keterampilan Menulis}

Salah satu aspek pengajaran keterampilan berbahasa adalah keterampilan menulis. Menulis berkaitan erat dengan tujuan pengajaran bahasa Indonesia itu sendiri dan meliputi tiga aspek yaitu. 
(1) tujuan pengajaran yang berkaitan dengan pembinaan sikap positif terhadap bahasa Indoneia, (2) tujuan pengajaran yang berkaitan dengan pembinaan pengetahuan tentang segi, bentuk, makna, dan fungsi bahasa Indonesia, serta (3) tujuan pengajaran yang berkaitan dengan pembinaan kemampuan penggunaan hahasa Indonesia.

Hal itu berarti bahwa membina siswa mampu atau terampil di dalam menggunakan bahasa Indonesia dengan baik dan benar dalam berbagai peristiwa komunikasi, karena menulis meningkatkan pembelajaran. Sehubungan dengan ini, Arikunto (1998) menyatakan bahwa kemampuan menulis yang merupakan keterampilan berbahasa produktif lisan melibatkan aspek penggunaan ejaan. kemampuan penggunaan diksi kosakata, kemampuan penggunaan kalimat penggunaan jenis komposisi (gaya penulisan, penentuan ide, pengolahan ide, dan pengorganisasian ide). Kesemua aspek itulah yang diukur dalam kemampuan menulis. Demikian pula, Syafi'ie (2001: 56) menyatakan bahwa tujuan pengajaran keterampilan menulis berkaitan erat dengan penggunaan bahasa dalam komunikasi tulis.

Aktivitas menulis merupakan kegiatan yang memerlukan kemampuan yang bersifat kompleks diantaranya adalah kemampuan berpikir secara sistematis, logis, serta kemampuan mengekspresikan gagasan atau pikiran secara jelas dengan menggunakan bahasa yang efektif, serta menerapkan kaidah tulis-menulis dengan baik (Rofi'uddin dan Zuhdi, 1997: 62). Dikatakan pula bahwa kapabilitas menulis yang diperlukan itu diperoleh melalui proses yang panjang. Anak didik sudah harus mulai menulis sejak tingkat awal, yakni mengenal lambang-lambang bunyi sampai pada tingkat akhir yaitu mampu dan terampil menulis. Kemampuan dan keterampilan menulis yang diperoleh pada tingkat permulaan menjadi (dasar untuk peningkatan dan pengembangan kemampuan selanjutnya. Sejalan dengan apa yang diungkapkan di atas, Akhadiah dkk (1988: 26) berpendapat bahwa kemampuan menulis yang dapat dikembangkan pada jenjang pendidikan dasar adalah kcmampuan reproduktif, reseptif-produktif, dan produktif.

Kegiatan yang dilakukan dalam kemampuan reproduktif ialah menyalin teks dan buku atau yang ditulis di papan tulis. Sebaliknya, kemampuan reseptif-produktif yakni teks diberikan kepada siswa. Teks itu merupakan teks tertulis yang dibaca oleh siswa atau yang diperdengarkan melalui kaset. Siswa diminta untuk memproduksi kembali teks tersebut secara keseluruhan atau sebahagian (intinya) saja. Kedua kemampuan ini memperlihatkan bahwa siswa masih terikat dengan teks yang diberikan, terutama mengenai isi,jalan cerita, dan konsep pemikiran.

Anak didik harus menulis secara bebas berdasarkan tema yang diberikan dengan menggunakan beberapa kata kunci untuk mengembangkan kemampuan produktifnya. Aktivitas yang dilakukan adalah mengonsep isi cerita, menyusun bahasa, dan membuat komposisi yang sesuai dengan apa yang ditentukan. Bentukbentuk kemampuan menulis itu disebutkan oleh Nurgiyantoro sebagai tugas kemampuan menulis. Diungkapkan pula bahwa ada tujuh tugas kemampuan menulis yang perlu diperhatikan yaitu (1) tugas menyusun kalimat, (2) menulis berdasarkan rangsang visual, (3) menulis berdasarkan rangsang suara. (4) menulis dengan rangsang buku, (5) menulis laporan, (6) menulis surat, (7) menulis berdasarkan tema tertentu. (Nurgiyantoro, 1987: 273-278).

\section{Rambu-rambu Pembelajaran Menulis}

Pada dasarnya, belajar bahasa adalah belajar berkomunikasi. Pembelajaran bahasa Indonesia diberikan untuk meningkatkan kemampuan siswa dalam berkomunikasi dan berekspresi secara lisan maupun tulisan. Pembelajaran bahasa Indonesia yang disajikan mencakup komponen kebahasaan, pemahaman, serta penggunaan untuk disajikan kembali secara terpadu. Sebaliknya, guru dapat memusatkan perhatiannya pada salah satu komponen dalam pembelajaran.

Pembagian waktu serta penentuan satu fokus komponen dalam satu pertemuan, atau seluruh waktunya untuk satu komponen dapat diatur sendiri oleh guru SMK. Pembejalaran kebahasaan ditujukan untuk peningkatan kemampuan pemahaman dan penggunaan bahasa. Melalui penelitian ini kiranya dapat dioptimalisasikan upaya peningkatan kemampuan menulis narasi dalam pembelajaran bahasa Indonesia siswa dengan memperhatikan prinsipprinsip pengajaran secara urut, mulai dari yang mudah sampai yang sukar, dekat ke jauh, sederhana ke rumit, yang diketahui ke yang tidak diketahui, dan yang konkret ke yang abstrak. 
Sasaran pembelajaran bahasa Indonesia tidak lain untuk mempertajam kepekaan perasaan siswa. Siswa dapat mampu menyikapi informasi yang disampaikan, baik secara langsung maupun secara terselubung melalui peningkatan empat aspek keterampilan berhahasa yaitu, menyimak, berbicara, membaca dan menulis. Dalam hal itu, siswa akan banyak berlatih tentang bagaimana meningkatkan keterampilan menulis khususnya menulis narasi. Hubungan serta realisasi yang dapat diwujudnyatakan adalah mendengar-menulis, berdiskusi-menulis, bercakap-cakap-menulis, dan membaca-menulis, memerankan-menulis, atau melaporkan-membahas, atau membahas-menulis.

Kegiatan pembelajaran tersebut selain untuk peningkatan keterampilan berbahasa juga kemampuan berpikir, bernalar, dan kemampuan memperluas wawasan. Konteks atau tema yang digunakan untuk pengembangan dan perluasan perbendaharaan kata siswa serta pemersatu kegiatan bahasa. Hal itu bertujuan agar pembelajaran bahasa dapat berlangsung dalam suasana kebahasaan yang wajar.

Kegiatan belajar mengajar senantiasa tetap mengacu pada sasaran agar siswa dapat terampil menggunakan empat aspek bahasa tersebut. Pembelajaran kosakata dapat dipadukan dengan pembelajaran seperti percakapan, membaca, menulis, menyimak dan sastra. Upaya memperbanyak kosakata dilaksanakan secara terusmenerus dan mencakup berbagai bidang.

Materi pelajaran kebahasaan mencakup lafal, ejaan, tanda baca, kosakata, struktur, paragraf, dan wacana. Lafal yang baik dan wajar perlu diperkenalkan sejak dini, begitu pula pengucapan serta intonasi, bahkan tanda-tanda haca. Wacana pembelajaran yang bertalian dengan pemahaman diambil dari bahan mendengarkan dan membaca, yang meliputi pengembangan kemampuan untuk menyerap gagasan, pendapat, pengalaman, pesan, dan perasaan yang diekspresikan secara lisan atau tertulis. Bahan pelajaran bahasa dan Sastra Indonesia dapat dipadukan atau dikaitkan dengan mata pelajaran lain seperti IPA, IPS, atau Matematika. Bahan pelajaran tersebut berguna untuk: (1) memupuk jiwa dan moral Pancasila. (2) fungsional, berisi pengetahuan, keterampilan, teknologi, dan kesenian, (3) sesuai dengan taraf perkembangan siswa. (4) faktual seperti bercakap-cakap, dan (5) memenuhi tujuan pendidikan, yakni bahan yang akan digunakan sebagai bekal melanjutkan ke jenjang pendidikan yang lebih tinggi.

Guru dapat memilih metode yang dianggap tepat, sesuai dengan tujuan, materi, dan keadaan siswa sehingga metode pengajaran tidak disajikan secara khusus dalam GBPP. Kegiatan untuk tugas yang beragam baik perorangan, pasangan, kelompok, ataupun keseluruhan kelas dapat dilakukan di dalam ataupun di luar kelas. Buku sumber berupa buku (pelajaran) wajib, buku (pelengkap) suplemen, buku bacaan novel, cerpen. Selain itu, ada pula kamus, dan ensikiopedia, juga media cetak, surat kabar, dan majalah serta media elektronik seperti radio, tape recorder, video. tclevisi, dan kaset. Cerita narasi yang ada dan berhubungan dengan dongeng seperti hikayat, malingkundang.

Menurut Mustakim, (1994) proses menulis bisa dikaji dan dipahami. Untuk memproduksi suatu hasil penulisan yang baik dapat dilakukan dengan menciptakan kembali separuh dan apa yang dibuat siswa maupun penulis profesional. Dikatakannya bahwa proses menulis tidak bersifat linear tetapi rekursif. Penulis melewati proses menulis sekali atau beberapa kali dan memberikan penekanan pada tahap-tahap yang berbeda dalam setiap jalur penulisannya. Aspek kognitif kepribadian penulis yang singkron dengan pengalaman serta hakikatnya memberikan suatu 'support' untuk melaksanakan tugas menulis walaupun proses menulis itu sangat beragam bentuknya. Guru dalam proses belajar mengajar hendaknya memberikan banyak kesempatan kepada para siswanyà untuk menggambarkan topik yang akan ditulisnya sesuai tahapan proses menulis.

Sehubungan dengan hal tersebut, Hidayat dkk (1990) mengatakan bahwa proses menulis merupakan cara mengamati pelajaran menulis, di mana penekanan diubah dan produk akhir siswa menjadi apa yang dipikirkan siswa dan apa yang mereka lakukan saat menulis. Ada lima tahap yakni (1) tahap pramenulis, (2) tahap drafting, (3) tahap merevisi, (4) tahap mengedit, dam (5) tahap mempublikasikin. Tahapan ini terjadi secara berulang kali saat siswa menulis.

Kelima tahap di atas dapat diimplementasikan sebagai berikut: (1) Tahap pramenulis difokuskan pada penulisan prediksi yang diawali dengan kegiatan motivasi, pembangkitan skemata dan pembacaan dalam hati wacana yang diberikan guru serta dibuatkan pemaparan tentang wacana narasi tersebut. (2) Tahap penulisan 
perevisisan, prediksi, pengeditan ejaan, tanda baca didahului dengan kegiatan memahami teks wacana narasi lengkap dan diakhiri dengan kegiatan penyalinan kembali ringkasan yang sudah dilengkapi, direvisi, dan diedit. Pada tahap pemublikasian difokuskan pada sharing berpasangan dan menginterpretasikan naskah yang sudah siap untuk dipublikasikan.

\section{E.Pembelajaran Kooperatif}

Pembelajaran kooperatif salah satu bentuk pembelajaran yang berdasarkan faham kontruktivis. Pembelajaran kooperatif merupakan strategi belajar dengan sejumlah siswa sebagai anggota kelompok kecil yang tingkat keterampilannya berbeda. Dalam menyelesaikan tugas kelompoknya, setiap anggota siswa anggota kelompok harus saling bekerja sama dan saling membantu untuk memahami materi pelajaran. Dalam pembelajaran kooperatif, belajar dikatakan belum selesai jika salah satu teman dalam kelompok tidak menguasai bahan pelajaran.

Unsur-unsur dalam pembelajaran kooperatif adalah sebagai berikut (Aminuddin, 2001).

1. Pada siswa harus memiliki persepsi mereka harus saling bekerja sama.

2. Para siswa harus memiliki tanggung jawab terhadap siswa atau peserta didik lain dalam kelompoknya, sealing tanggung jawab terhadap diri sendiri dalam pembelajaran materi yang dihadapi.

3. Para siswa harus berpandangan bahwa mereka semua memiliki tujuan yang sama.

4. Para siswa membagi tugas dan berbagai tanggungjawab di antara para anggota kelompok.

5. Para siswa diberikan satu evaluasi atau penghargaan yang ikut berpengaruh terhadap evaluasi kelompok.

6. Para siwa berbagai kepemimpinan sementara mereka memperoleh keterampilan bekerja sama selama belajar.

7. Setiap siswa akan diminta mempertanggungjawabkan secara individu meteri yang ditangani dalam kelompok kooperatif.

Pembelajaran kooperatif siswa belajar

bersama dalam kelompok-kelompok kecil yang saling membantu satu sama lain. Kelas disusun dalam kelompok yang terdiri atas empat atau enam orang siswa, dalam keterampilan yang heterogen. Maksud kelompok heterogen adalah terdiri atas campuran atas keterampilan siswa, jenis kelamin dans uku. Hal ini bermanfaat untuk melatih siswa menerima perbedaan dan bekerja sama dengan teman yang berbeda latar belakang.

Pada pembelajaran kooperatif diajarkan keterampilan-keterampilan khusus agar dapat bekerja sama dengan baik dalam kelompoknya, seperti menjadi pendengar yang baik, siswa diberi lembar kegiatan yang berisi pertanyaan atau tugas yang direncanakan untuk diajarkan. Selama kerja kelompok, tugas anggota kelompok adalah mencapai ketuntasan (Slavin, 1995).

Beberapa ciri pembelajaran kooperatif adalah: (a) setiap anggota memiliki peran, (b) terjadi hubungan interaksi langsung di antara siswa, (c) setiap anggota kelompok bertanggung jawab atas belajarnya dan juga teman-teman sekolompoknya, (d)guru membantu pengembangkan keterampilan-keterampilan interpersional kelompok, (e) guru hanya berinteraksi dengan kelompok saat diperlukan.

Tiga konsep sentral yang menjadi karakteristik pembelajaran kooperatif sebagaimana dikemukakan oleh Slavin (1995), yaitu penghargaan kelompok, pertanggungjawaban individu, dan kesempatan yang sama untuk berhasil.

1. Penghargaan kelompok

Pembelajaran kooperatif merupakan tujuan-tujuan kelompok untuk memperoleh penghargaan kelompok. Penghargaan kelompok diperoleh jika kelompok mencapai skor di atas kriteria yang ditentukan. Keberhasilan kelompok didasarkan penampilan individu sebagai anggota kelompok dalam menciptakan hubungan antarpersonal yang saling mendukung, saling membantu, dan saling peduli.

2. Pertanggungjawaban individu

Keberhasilan kelompok bergantung pada pembelajaran individu dari semua anggota kelompok yang saling membantu dalam belajar. Adanya pertanggungjawaban secara individu juga menjadikan setiap anggota siap menghadapi tes dan tugas-tugas lainnya secara individu juga menjadikan setiap anggota siap untuk menghadapi tes dan tugas-tugas lainya secara mandiri tanpa bantuan teman sekolompoknya.

3. Kesempatan yang sama untuk mencapai keberhasilan

Pembelajaran kooperatif menggunakan metode skoring yang mencakup nilai perkembangan berdasarkan peningkatan prestasi 
yang diperoleh siswa dari yang terdahulu. Dengan mengunakan metode skoring ini setiap siswa, baik yang berprestasi rendah, sedang, atau tinggi samasama memperoleh kesempatan untuk berhasil dan melakukan yang terbaik dalam kelompoknya.

Tujuan pembelajaran kooperatif berbeda dari kelompok tradisional yang menerapkan sistem kompetisi, sehingga keberhasilan individu diorentasikan pada kegagalan orang lain, sedangkan tujuan pembelajaran kooperatif adalah menciptakan situasi sehingga keberhasilan individu ditentukan atau dipengaruhi oleh keberhasilan kelompoknya (Slavin, 1995).

Model pembelajaran kooperatif dikembangkan untuk mencapai setidak-tidaknya tiga tujuan pembelajaran penting yang dirangkum oleh Nurgiantoro dkk (1998), yaitu:

1. Hasil belajar akademik

Dalam belajar kooperatif selain mencakup beragam tujuan sosial, juga memperbaiki prestasi siswa atau tugas-tugas akademis penting lainnya. Beberapa ahli berpendapat bahwa model ini unggul dalam membantu siswa memahami konsep-konsep sulit. Para pengembang model ini unggul telah menunjukkan bahwa model struktur model penghargaan kooperatif telah dapat meningkatkan nilai siswa pada belajar akademik dan perubahannorma yang berhubungan dengan hasil belajar. Di samping mengubah norma yang berhubungan dengan hasil belajar, pembelajaran kooperatif dapat memberikan keuntungan, baik pada siswa kelompok bawah maupun kelompok atas yang bekerja bersama menyelesaikan tugastugas akademik.

2. Penerimaan terhadap perbedaan individu

Tujuan lain model pembelajaran kooperatif adalah penerimaan secara luas dari orang-orang yang berbeda berdasarkan ras, budaya, kelas sosial, keterampilan, dan ketidakmampuannya. Pembelajaran kooperatif memberi peluang bagi siswa dari berbagai latar belakang dan kondisi untuk bekerja dengan saling bergantung pada tugas-tugas akademik dan melalui struktur penghargaan koopertif akan belajar saling menghargai satu sama lain.

3. Pengembangan keterampilan sosial

Tujuan penting ketiga pembelajaran kooperatif adalah mengajarkan kepada siswa, keterampilan bekerja sama dan kolaborasi. Keterampilan-keterampilan sosial penting dimiliki oleh siswa sebab saat ini banyak anak muda dalam keterampilan sosial.

\section{Keterampilan kooperatif}

Dalam pembelajaran kooperatif tidak hanya mempelajari materi saja, tetapi siswa atau peserta didik juga juga harus mempelajari keterampilan-keterampilan khusus yang disebut dengan keterampilan kooperatif. Keterampilan kooperatif ini berfungsi melancarkan hubungan kerja dan tugas. Peranan hubungan kerja dapat dibangun dengan membangun tugas anggota kelompok salama kegiatan. Keterampilanketerampilan selama kooperatif tersebut antara lain sebagai berikut (Nurgiantoro dkk, 1987).

1. Keterampilan kooperatif tingkat awal

1. Menggunakan kesepakatan. Mengandung arti menyamakan pendapat yang berguna untuk meningkatkan hubungan kerja dalam kelompok.

2. Menghargai kontribusi. Menghargai berarti memperhatikan atau mengenal halhal yang dapat dikatakan atau dikerjakan anggota lain. Hal ini berarti harus selalu setuju dengan anggota lain, dapat saja kritik yang diberikan itu ditujukan ide dan tidak individu.

3. Mengambil giliran dan berbagai tugas. Pengertian ini mengandung arti bahwa setiap anggota bersedia menggantikan dan bersedia mengembang tugas/tanggung jawab tertentu dalam kelompok.

4. Berada dalam kelompok. Maksud di sini adalah setiap anggota tetap dalam kelompok kerja selama kegiatan berlangsung.

5. Berada dalam tugas. Yang dimaksud berada dalam tugas adalah meneruskan tugas yang menjadi tanggung jawab, agar kegiatan dapat diselesaikan sesuai dengan waktu yang dibutuhkan.

6. Mendorong partisipasi. Mendorong partisipasi berarti mendorong semua anggota kelompok untuk memberikan kontribusi terhadap tugas kelompok.

7. Menyelesaikan tugas pada waktunya.

8. Menghormati perbedaan individu. Menghormati perbedaan individu berarti sikap menghormati terhadap budaya, suku, ras, atau pengalaman dari semua siswa atau peserta didik.

2. Keterampilan tingkat menengah

Keterampilan tingkat menengah meliputi, menunjukkan penghargaan dan simpati, mengungkapkan ketidaksetujuan dengan cara dapat diterima, mendengarkan dengan arif, bertanya, 
membuat ringkasan, menafsirkan, mengorganisasi dan mengurangi ketegangan.

\section{F. Strategi Pembelajaran Model STAD}

Salah satu metode untuk mengajarkan informasi akademik baru kepada siswa, baik melalui penyajian verbal maupun tertulis adalah metode $S T A D$. Dalam mengaplikasikan metode itu, para siswa di dalam kelas yang dibagi dalam beberapa kelompok itu memiliki kemampuan tinggi, sedang, dan rendah. Tiap anggota tim menggunakan lembar kerja akademik, dan kemudian siswa yang saling membantu untuk menguasai bahan ajar melalui tanya jawab, atau diskusi antarsesama anggota itu.

Pembelajaran menulis narasi akan dievaluasi oleh guru untuk mengetahui penguasaan terhadap bahan akademik yang telah dipelajari baik secara individual maupun tim. Tiap siswa dan tiap tim diberi skor terhadap penguasaan bahan ajar, dan kepada siswa secara individu atau tim yang meraih prestasi tinggi atau memperoleh skor sempurna diberi pengharapan (Syafii, 2001).

Strategi Student Teams' - Achievcment Divisions (STAD,) adalah suatu metode pembelajaran kooperatif untuk pengelompokan kemampuan campur yang melibatkan pengakuan kelompok tim dan tanggung jawab kelompok/tim tersebut untuk pembelajaran individu aggota.

Menurut Slavin (1994) siswa ditempatkan dalam tim belajar beranggotakan empat orang yang merupakan campuran menurut tingkat kinerja, jenis kelamin, dan suku. Guru menyajikan pelajaran, dan kemudian siswa bekerja di dalam kelompok/tim mereka untuk memastikan bahwa seluruh anggota kelompok/tim telah menguasai pelajaran tersebut. Akhirnya, seluruh siswa dikenai kuis tentang materi tersebut. Sewaktu kuis dilaksanakan mereka tidak dapat saling membantu. Skor siswa dibandingkan dengan rata-rata skor mereka sendiri yang lalu dan nilai diberikan berdasarkan pada seberapa jauh siswa menyamai atau melampui kinerja sendiri yang lalu. Nilai tiap anggota tim ini dijumlahkan untuk mendapatkan skor tim, dan tim yang mencapai kriteria tertentu dapat diberi sertifikat atau ganjaran yang lain.

\section{G. Langkah-Iangkah Pembelajaran Menulis narasi dengan Strategi $S T A D$}

Bagian berikut ini mengungkapkan paparan tentang langkah-langkah atau aktivitas yang dilaksanakan oleh guru maupun siswa dalam menulis narasi. Langkah-Iangkah dimaksud mengkuti tatanan proses menulis sebagai berikut (1) menentukan apa yang akan dipaparkan dalam penulisan, (2) merumuskan tujuan penulisan, (3) menetapkan bagian yang akan digambarkan, (4) merinci hal penunjang kekuatan yang akan dituliskan.Menulis narasi juga mengikuti tahapan proses menulis yaitu, tahapan pramenulis, penulisan draf, revisi, editing, dan publikasi (Rofi'uddin, 2001: 195). (1) Kegiatan pada tahap pramenulis adalah, (a) memilih topik, (b) menentukan tujuan menulis, (c) mengidentifikasi pemikiran sesuai topik serta merencanakan pengorganisasiannya, (d) mengidentifikasi karangan yang ditulis, (e) memilih bentuk karangan berdasarkan tujuan penulisan; (2) Pada tahap penulisan draf adalah penulis menuangkan gagasan, pikiran, dan perasaan dalam draf kasar, (3) Pada tahap revisi kegiatan adalah, (a) menambahkan informasi, (b) lebih mempertajam perumusan, (c) mengubah urutan pemikiran, (d) menghilangkan cerita yang tidak relevan, (e) menyatukan pemikiran ke dalam tulisan. (4) Pada tahap editing penulis mengedit tulisannya dengan, (a) menelaah seluruh tulisan, (b) memperbaiki kata yang kurang tepat, (c) koreksi kesalahan ketik, (d) membetulkan teknik penomoran, (e) memperbaiki ejaan dan tanda baca. (5) Tahapan publikasi, penulis memublikasikan tulisannya melalui berbagai media, terkirim ke penerbit, majalah, atau ditampilkan pada majalah sekolah dalam bentuk majalah dinding.

Guru melakukan (1) Perencanaan pembelajaran, siswa ditugasi mencermati isi karangan narasi, mendiskusikannya dalam kelompok, dan melaporkan hasil diskusi kelompok sebagai hasil pemaparannya. (2) setiap kelompok ditugas menarasikan pemaparannya tentang apa yang dibahas serta materi lainnya yang relevan. (2) Pelaksanaan Mengajar. Dalam pelaksanaan kegiatan pembelajaran menulis narasi terdapat kegiatan-kegiatan sebagai berikut (a) Kegiatan pramenulis untuk mengetahui respon siswa terhadap penjelasan guru tentang tema, tujuan, langkah pembelajaran, membangkitkan skemata, dan keterlibatan siswa menginterpretasi, serta menentukan topik karangan. (b) Kegiatan yang dilakukan pada tahap menulis, yaitu keterlibatan siswa dalam menyusun dan mengembangkan draf eksposisi. (c) Kegiatan pada tahap pascamenulis adalah keterlibatan siswa memperbaiki atau 
merefisi draf yang telah disusun pada lembar kerja siswa.

\section{H. Bentuk Penilaian dalam Pembelajaran Model STAD}

Nurhadi (2004: 130) menyatakan bahwa dalam kegiatan belajar-mengajar digunakan (1) penilaian proses dan kinerja, yakni (a) penilaian terhadap keseriusan siswa dalam kerja kelompok, mengetahui aktivitas, kreativitas, partisipasi, dan kesungguhan hati siswa dalam belajar. (b) inisiatif individu dalam mengikuti kegiatan pembelajaran, yakni apakah selama menunggu instruksi guru saja untuk pelaksanaan kegiatan pembelajaran, atau selalu ada inisiatif, dan kreativitas sendiri, (c) kemampuan siswa mempresentasikan hasil karyanya. Kemampuan dan keterampilan siswa dalam belajar tidak sama dan merata. Walaupun begitu, siswa ikut terlibat, aktif dan kreatif di setiap kegiatan pembelajaran kelompok, (2) penilaian hasil kerja kelompok dan individu yakni untuk (a) rencana kegiatan tertulis dan display siswa. Setiap siswa membuat rencana kegiatan tertulis dan display untuk dipedomani dan dilaksanakan pada kegiatan pembelajaran, (b) keakuratan dalam pembuatan rancangan. Setiap siswa membuat rancangan, baik anggaran maupun rencana lainnya seperti pembuatan kerangka cerita, dan lain-lain. Penilaian siswa seperti, (1) penilaian kualitas

\section{METODE PENELITIAN}

\section{HASIL PENELITIAN}

Paparan hasil penelitian ini dikategorikan dalam tiga Bagian, yakni hasil penelitian sikius I, hasil penelitian siklus II, dan hasil penelitian sikius III. Ketiga siklus tersebut dipaparkan secara terpisah untuk melihat persamaan, perbedaan, perubahan, dan perkembangan alur siklus. Hasil penelitian ini dipaparkan secara rinci sebagai berikut.

Setiap siklus tindakan pembelajarari menulis narasi dengan strategi belajar kelompok (STAD) merupakan suatu proses yang utuh dan terpadu mencakup: (1) upaya peningkatan kemampuan siswa menulis narasi melalui strategi STAD pada tahap perencanaan pembelajaran, (2) upaya peningkatan kemampuan siswa menulis narasi dengan strategi STAD pada tahap pelaksanaan pembelajaran, (3) upaya peningkatan pekerjaan atau hasil belajar, (2) penilaian kualitas kerja sama antaranggota kelompok tim. Meskipun dirasakan kurang waktu belajar di kelas, siswa tetap memerlukan waktu berdiskusi dengan teman lain. Hal tersebut agar siswa dapat membahas kualitas kerja sama antaranggota kelompok pada hari itu. Pembicaraan dengan siswa dilakukan untuk mengetahui apa yang telah dilakukan dan apa yang masih perlu ditingkatkan pada har-hari berikutnya.

Terkait dengan penilaian di atas, yang perlu dinilai yaitu: (1) apakah siswa sudah menggunakan tanda baca dengan tepat?, (2) apakah siswa sudah menggunakan huruf benar dan katakata sambung dengan tepat?, (3) apakah siswa menggunakan pikiran yang logis?, (4) apakah kelengkapan tulisan, huruf, kata lainnya sudah baik?, (5) apakah karangan bagus dan bersih (Depdikbud. I 995).

Pada sisi lain, menilai proses dengan cara mengamati siswa saat mereka menulis dengan mengajukan pertanyaan: (1) apakah siswa mengaplikasikan elemen dalam paparan yang ditulis?, (2) menulis prediksi? (3) berpartisipasi dalam kelompok menulis?, (4) merevisi prediksi menurut umpan balik yang diterima dari kelompok menulis'?, (5) mengoreksi cerita dan memperbaiki sebanyak mungkin kesalahan mekanik?, dan (6) menunjukkan (narasi)?

kemampuan menulis narasi dengan strategi STAD pada tahap evaluasi pembelajaran, (4) observasi pembelajaran, dan (5) rangkuman tindakan dan refleksi tindakan serta masalah yang ditemui pada pelaksanaan tindakan setiap siklus. Sebelum melaksanakan tindakan pada siklus I peneliti dan praktisi mengadakan tes awal untuk mengetahui kemampuan siswa secara individu dalam menulis narasi (pemaparan) tentang kegemarannya. Tujuannya ialah untuk mengetahui kemampuan siswa tentang penulisan ejaan. tanda baca, pemakaian huruf kapital, kalimat yang baik dan benar, pemahaman tentang paragrafutama, paragraf penjelas, gagasan utama wacana, gagasan penjelas, dan ide pokok.

\section{PENUTUP}


Kesimpulan

Berdasarkan pada hasil penelitian dan pemaparan. Simpulan yang lebih berkaitan dengan karakteristik strategi menulis narasi dalam meningkatkan kemampuan menuangkan gagasan dalam menulis narasi dengan mengikuti langkahIangkah dalam pendekatan menulis narasi.

Kegiatan yang dilakukan adalah dalam upaya meningkatkan kcrnampuan menuangkan gagasan dalam menulis narasi meialui strategi STAD pada tahap pramenulis yang meliputi pembangkitan skemata, penggalian gagasan, menyampaikan kompetensi dasar, menyampaikan langkah-langkah menulis, memberi contoh model tuisan narasi, dan membimbing siswa membuat kerangka karangan.

Selain itu, diketahui bahwa ke sembilan telah dapat:

(1) memiiki gagasan dan pengetahuan dan pengalaman untuk dikernbangkan dalam sebuah tulisan, (2) memahami dan mengaplikasikan contoh tulisan narasi yang ditampilkan, (3) mengembangkan tema karangan dan memilih topik sesuai minat, pengetahuan dan pengalaman siswa, (4) menulis judul karangan, dan (5) menyusun kerangka karangan. Kelima hal tcrsebut merupakan langkah awal bagi siswa untuk menulis drafkarangan.

Pemilihan topik berdasarkan minat siswa. Dengan memberikan kebebasan kepada siswa untuk memilih topik merupakan salah satu aspek yang diperlukan sebagai kesiapan dasar untuk dapat menulis dengan lancar. Hal itu disebabkan oleh judul yang dipilih siswa sesuai dengan pengetahuan dan pengalaman yang dimilikinya. Contoh atau mod\& yang ditampilkan dalam bentuk karangan dapat membangkitkan skemata siswa untuk menuangkan gagasannya ke dalam bentuk karangan. Dengan demikian, siswa dapat dibimbing untuk mendeskripsikan sesuatu secara tertulis melalui contoh/model ekskposisi dan pengetahuan serta pengalaman yang mereka miliki.

Topik yang telah dikembangkan dipilih sesuai minat, pengetahuan dan pengalaman mereka. Arahan guru sangat membantu siswa dalam menyusun kerangka karangannya sesuai bentuk yang ditampilkan.

2. Pembelajaran Menulis narasi Melalui trategi STAD pada Tahap Menulis

Pelaksanaan pembelajaran menulis cksposisi melalui strategi STAD) pada tahap menulis mernperlihatkan bahwa ke sembilan siswa terteliti telah mampu (1) menulis drafkarangan, (2) bekerja sarna dalarn kelompok, (3) menulis karangan narasi, (4) menyelesaikan tugas mengarang narasi, dan (5) melakukan revisi dan penyuntingan karangan. Dengan pembendaharaan praktis dari peneliti disertai motivasi guru, serta contoh dan bentuk narasi yang disajikan siswa dapat menemukan dan menuangkan gagasannya ke dalam bentuk tulisan narasi.

3. Pembelajaran Menulis narasi Melalul Strategi STAD pada Tahap Pasacamenulis

Kegiatan pembelajaran pada tahap pascamenulis adalah (1) membaca basil karangan, (2) memberikan tanggapan karangan siswa, (3) mernberi saran kepada teman sebagai penyempumaan karangan, (4) menyempurnakan karangan sesuai saran teman, (5) memajan hasil karangan di papan tulis untuk dibacakan secara kiasikal. Ditemukan bahwa pada saat awal pembelajaran siswa masih takut dan niau serta ragu-ragu.

Namun, siswa memiliki spontanitas dan rasa percaya din setelah diberikan kesempatan kepada temannya untuk menyuntingkan karangannya. Sikap kritis tersebut adalah konkritisasi dan sikap kritis, konstruktif, dan kera sama yang baik serta toleran. Sekalipun berbeda pendapat, namun dapat diterima secara baik dan transparan. Hal ini membuat siswa percaya diri, berani dan bertanggung jawab. Sikap positif sedemikian sangat diharapkan agar siswa dapat mengaplikasikannya dalam pembelajaran

Banyak kegiatan yang dapat dilakukan dikelas agar siswa hisa melkukan komunikasi den gan balk diantaranya, bertukar pikiran dan berbagi pengalaman, berdialog dengan teman sejawat dalam suasana yang aktif dan komunikatif: Hal ini dapat menumbuhkan rasa percaya diri siswa, termotivasi dan meningkatkan kemampuan menulisnya terutama menulis narasi.

4. Evaluasi Pembelajaran Menulis eksposisi Melalui Strategi STAD Kegiatan evaluasi pembelajaran menulis narasi melalui strategi STAD adalah evluasi proses dan evalusi hasil pembelajaran. Evaluasi proesmeliputi aktivitas siswa dalarn mengikuti pembelajaran menulis eksposisi melalui strategi STAD meliputi tahap pramenulis. menulis, dan pascamenulis. 


\section{DAFTAR PUSTAKA}

khadiah, S . 2001. Maleri Pokok Menulis I. Jakarta: U41Rersitas Terhuka.

khadiah, S., Arsyad, M.G., \& Ridwan, S. 1988. Kemampuan Menulis Baha

Indonesia. Jakarta: Erlangga

Aminuddin, 1996. Pendekatan dan Pengajaran Bahasa dan Sastra. 1PS IKIP Malang.

. rrikunto, S. 1998. Prosedur Penelitian Suatu Pendelcatan Prakiek. Jakarta Rineka Cipta.

Bogdan, R. C. \& Bikien, S. K. 1992. Qualitative Re.searchfor Education: An

Introduction to Theory and Methods. Boston: Allyn and Bacon.

Chomsky, N. 1971. Language and Mind. New York: Harcourt Brace Javanovich.

Clay, M. 1975. What did I Write? Beginning Writing Behaviour. Portsmouth, NI-I:

Heinemann

Cleary, L., M. \&Linn,.M. D. 1993. Linguisricfor Teachers. New York: Mc Grav Hill.

Cohen, L. and Linn, M.D. 1986. Linguistics for Teachers. New York: Mc Graw lull.

Cohen, L. \& Manion, L. 1989. Research Methods in Education. London: Ne l'ctcr Lane

Combs, M. 1996. Developing Competent Readers and Writers in the Primary Grades.

NIerriI, an imprint of Prentice 1-lall [nglewood Cliffs, New ersey:

Columbus Ohio.

Cox, Carole., \& Zarrilo, J. 1993. Teaching Reading with Children Literature. Ncw

York: Macrnlilian Publishing Company.

Crawley, S.J.,\& Mountain, L.H. 1988. Strategies jir Guiding content Reading.

Boston: Allyn and Bacon

Culinan, B. E. 1989. Literature And The Child Second Edition. New York:

Harcourt Brace Javanovich, Publishers.

Darwis, M. $\quad$ D. 2004. PenerapanStrategiInkuiridalarnMeningkaikinPc,nh clujaran

Menulis Paragraf Narasi di Kclas II SLTP Negeri 2 Dolo Sulawesi

Terigah. Tesis tidak diterbitkan. Malang: Universitas Negeri Malang. 